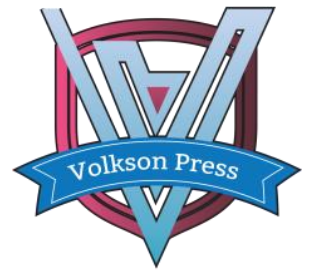

Contents List available at VOLKSON PRESS

Economics \& Management Innovations(EMI)

DOI : http://doi.org/10.26480/icemi.01.2017.397.400

\title{
Maintenance Stakeholders from OEE perspective - case study
}

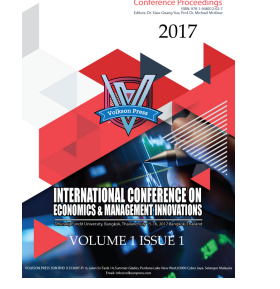

\author{
Przemysław Drożyner ${ }^{1, *}$, Małgorzata Jasiulewicz-Kaczmarek ${ }^{2}$ \\ ${ }^{1}$ University of Warmia and Mazury in Olsztyn, Oczapowskiego Street 11, 10-719 Olsztyn, Poland \\ ${ }^{2}$ Poznan University of Technology, Strzelecka Street 11, 60-965 Poznan, Poland \\ *przemas@uwm.edu.pl
}

This is an open access article distributed under the Creative Commons Attribution License, which permits unrestricted use, distribution, and reproduction in any medium, provided the original work is properly cited.

\section{ARTICLE DETAILS}

\section{Article History:}

Received 02 october 2017 Accepted 06 october 2017 Available online 11 october 2017

Keywords: Maintenance stakeholders, Overall Equipment Effectiveness, Reliability Centered Maintenance..

\section{ABSTRACT}

One of the principles of management systems says that if something cannot be measured, it cannot be improved too. In such approach, it is clear that formalized, the numerical assessment of efficiency of machines and devices which are usually the basis of an enterprise - becomes crucial. The literature many ways of such calculations are presented for instance reliability and durability indicators, different kinds of Overall Equipment Effectiveness (OEE) or so called Maintenance Key Performance Indicators. In this paper authors describe an original OEESIM method (OEE Stakeholders Identification Method). The method defines the concept of machine stakeholder, i.e. the person / department which is dependent on its proper operation or affects (has influence on) its proper operation.

\section{Introduction}

Maintenance services become an indispensable part of most business processes carried out by companies, from its primary goal, which was providing production continuity, through planning, logistics and sales, but also human resources management (concerning competencies, entitlements, hours of maintenance staff work) or occupational health and safety and environmental protection [1]. It is evident that maintenance activities are interdisciplinary and that achieving productive, qualitative, environmental and work-related goals requires engaging in technical issues (degradation, consumption, diagnostics, technical and technological progress), as well as in legal, regulatory and management aspects $[2,3,4]$.

Hence, the following questions may be asked:

- $\quad$ Are effectiveness and efficiency of the use of technical facilities operated in enterprises influenced by maintenance services only?

- What is the impact of other departments such as production, sales or marketing departments on the operation of technical facilities?

A measure that can be used to assess the impact of particular organizational structures or processes taking place in an enterprise on the efficiency of the use of machines is the so-called Overall Equipment Effectiveness (OEE). This concept, dating back to 1988, is still up-to-date and constantly evolving. However, development mainly concerns new computational schemes, and according to the authors of this article, there is a lack of research on the impact of the selection of machines and devices to measure this indicator on the effectiveness of subsequent analyzes. The question arises as to whether such a selection of technical objects (machines, lines) is possible, so that the measured OEE value of this object best reflects the efficiency of all or most of the business processes in the enterprise?

\section{Investigation field}

\subsection{Maintenance management and its stakeholders}

Taking into account the complexity and variety of modern machinery and equipment and the actual and potential consequences of failures and their impact, it is necessary to assign new activities to maintenance staff $[5,6]$. The consequences mentioned can be felt not only in economic terms (increase or decrease in financial expenditure), but also in the environment (e.g. consumption of consumables, media) and social (eg human safety) $[7,8,9]$. At present, to determine the role of enterprise maintenance management, it is essential to identify all those who influence the effectiveness of maintenance activities and those who benefit from maintenance (maintenance stakeholders) and then manage their requirements and expectations.

The main goal of maintenance stakeholder management is to manage the relationship between the maintenance and its stakeholders. Maintenance management oriented on stakeholders is on one hand focused on goals of the stakeholders who are interested in work and results of maintenance management and on the other hand the stakeholders who influence maintenance performance success. Usually, stakeholders are groups of people who are the most important for overall success of maintenance. They have the ability to influence realization of maintenance operations and either win or lose depending on results of actions taken. Stakeholders can be of both internal and external character. In most cases the maintenance internal stakeholders are production departments, facilities, operating departments and administrative groups. Each maintenance stakeholders may have unique expectations and requirements regarding maintenance. If one would attempt to reach a consensus it would be that all stakeholders desire timely quality service at a fair price. Value!

\subsection{Overall Equipment Effectiveness}

The most common method utilized in measuring maintenance performance based on machine factors is the Overall Equipment Effectiveness indicator $[10,11,12,13,14]$. Nakajima, the father of the Total Productive Maintenance (TPM) has introduced OEE as a powerful yardstick for tracking work progress and improvement [15]. Nakajima (1988) defines the losses that reduce the effectiveness of the equipment, classifies it into six major categories and proves that OEE (OEE = Availability x Performance $x$ Quality) measurement is an effective way of analyzing the efficiency of a single machine in the manufacturing system. Overall Equipment Effectiveness is accepted as a non-financial measure of internal efficiency, i.e. this measure which was previously ignored by traditional accounting systems, determine increasing levels of customer satisfaction, which is now the compulsory route required to financial results (fig. 1). 


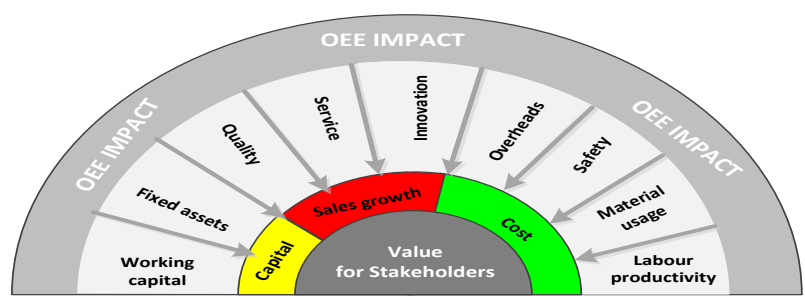

Figure 1. OEE impact on value for stakeholders

Non-financial measures are important complements to traditional financial measures, especially when it comes to day-to-day control of the manufacturing, as they are often more flexible and give fast feedback to the organization. It is therefore necessary to introduce the concept of "stakeholder" of machine/line, i.e. the person or department within the company, whose actions affect the efficiency of the use of machinery or depend on it. With this approach, the machine has more stakeholders; the more valuable - from the point of view of management processes in the company - can be an analysis of the effectiveness of its operation. There is a need to develop methods for the selection of such machines and manner of its metering so that the analysis of obtained results objectively reflected the functioning of different stakeholders.

Measuring equipment effectiveness must go beyond just availability or machine uptime [16, 17]. It must factor in all issues related to equipment performance. The formula for equipment effectiveness must look at the availability, the rate of performance and quality rate. This allows all departments to be involved in determining equipment effectiveness.

\section{Overall Equipment Effectiveness in a stakeholder's scenario}

The question arises as to whether such a selection of technical objects (machines, lines) is possible, so that the measured OEE value of this object best reflected the efficiency of all or most of the business processes in the enterprise?

The attempt to answer this question has led to identification of the need to use the term of a stakeholder, i.e. the organizational unit of an enterprise whose operation (or lack of it) can affect the efficiency of the use of the machine or its operation depends on that use. With this approach, it can be stated that the more a machine has stakeholders, the more valuable from the perspective of the enterprise can be its metering and analysis. There is therefore a need to develop a method for identifying these stakeholders and "measuring" selected machines so that the data collected identified the relationship on the line: stakeholder - the efficiency of the use of machines. The RCM (Reliability Centered Maintenance) method described in JA1011 standard: "Evaluation Criteria for ReliabilityCentered Maintenance Processes" was adapted to develop the methodology presented in the paper. According to the JA1011standard, the maintenance process can be referred to as RCM only after the seven questions shown in Table 1 are answered. The same table presents the equivalents of these questions in the methodology developed by the authors and called OEESIM (OEE Stakeholders Identification Method).

Tab.1. Questions in RCM and OEESIM [18]

\begin{tabular}{|c|c|c|c|}
\hline \multirow{2}{*}{ Question } & \multirow{2}{*}{ According to RCM } & \multicolumn{2}{|l|}{ According to OEESIM } \\
\hline & & Question & Goal \\
\hline 1 & $\begin{array}{l}\text { What are the } \\
\text { functions and } \\
\text { standards of the } \\
\text { desired efficiency of } \\
\text { an object in its } \\
\text { current operational } \\
\text { context? }\end{array}$ & $\begin{array}{l}\text { What are the functions } \\
\text { and standards of the } \\
\text { desired object } \\
\text { parameters in its } \\
\text { current operational } \\
\text { context in terms of } \\
\text { availability, } \\
\text { performance and } \\
\text { quality? }\end{array}$ & $\begin{array}{l}\text { Identification of } \\
\text { the desired } \\
\text { reference state in } \\
\text { terms of machine } \\
\text { operation. }\end{array}$ \\
\hline 2 & $\begin{array}{l}\text { How can an object } \\
\text { lose its functional } \\
\text { fitness? }\end{array}$ & $\begin{array}{l}\text { How can an object lose } \\
\text { its entire or partial } \\
\text { functional fitness? }\end{array}$ & $\begin{array}{l}\text { Identification of } \\
\text { factors affecting } \\
\text { the actual }\end{array}$ \\
\hline 3 & $\begin{array}{l}\text { What causes each of } \\
\text { these inabilities? }\end{array}$ & $\begin{array}{l}\text { What causes each of } \\
\text { these inabilities (or } \\
\text { deviation from the } \\
\text { given parameters)? }\end{array}$ & $\begin{array}{l}\text { utilization of the } \\
\text { machine }\end{array}$ \\
\hline 4 & $\begin{array}{l}\text { What are the visible } \\
\text { effects of the } \\
\text { inability? }\end{array}$ & $\begin{array}{l}\text { Who and why is } \\
\text { responsible for the } \\
\text { appearance of inability } \\
\text { (or deviation)? }\end{array}$ & $\begin{array}{l}\text { Identification of } \\
\text { machine } \\
\text { stakeholders }\end{array}$ \\
\hline
\end{tabular}

\begin{tabular}{|l|l|l|l|}
\hline 5 & $\begin{array}{l}\text { What are the } \\
\text { further } \\
\text { consequences of } \\
\text { each of these } \\
\text { inabilities? }\end{array}$ & $\begin{array}{l}\text { Who and how will be } \\
\text { affected by the effects } \\
\text { of inability or } \\
\text { deviation? }\end{array}$ & \\
\hline 6 & $\begin{array}{l}\text { What can be done to } \\
\text { foresee or prevent } \\
\text { any these } \\
\text { inabilities? the can loss of }\end{array}$ & $\begin{array}{l}\text { Hownctionality or } \\
\text { fun } \\
\text { deviation } \\
\text { measured? be }\end{array}$ & $\begin{array}{l}\text { Identification of } \\
\text { how the OEE } \\
\text { indicator and its } \\
\text { components are } \\
\text { calculated }\end{array}$ \\
\hline 7 & $\begin{array}{l}\text { What can be done if } \\
\text { it is not possible to } \\
\text { identify preventive } \\
\text { action? }\end{array}$ & $\begin{array}{l}\text { How to calculate the } \\
\text { OEE value for the } \\
\text { object? }\end{array}$ & \\
\hline
\end{tabular}

The more causes and effects of deviations and inconsistencies for an object are identified as a result of answering to questions 2-55, the more stakeholders the object has. Such a scheme was then applied to practical application in the enterprise processing poultry.

\section{Overall Equipment Effectiveness in a stakeholder's scenario}

\subsection{Object and scope of investigation}

Identification of stakeholders with the method developed by the authors was implemented in a company employing around 300 people and specialized in the production and processing of poultry meat on the technological lines shown in Figure 2.

\begin{tabular}{|l|c|}
\hline & poultry processing lines \\
\hline poultry slaughter line poultry cutting lines
\end{tabular}

Figure 2. Technological lines in the company

For each technology line, stakeholders are identified, ie organizational units of the company that either affect the efficiency of the operation of the line or are dependent on that efficiency.

As an example, Table 2 shows the next steps in the process of identifying stakeholders for the packaging line, the core of which is the MULTIVAC R$7000 \mathrm{~T}$. This is a multi-purpose roll packaging machine that automatically produces packaging from two separate foil roles: bottom, thermoformable, which creates a "pocket" for the product to be packaged and the top that represents the top of the packaging. The machine enables the production of packaging sizes from $20 \mathrm{~mm} \times 47.5 \mathrm{~mm}$ to $600 \mathrm{~mm} \times$ $800 \mathrm{~mm}$. Machine performance depends on the product being packaged from 8 packs of $19 \mathrm{~kg}$ of meat to 900 packs of small products per minute. In the company under consideration the machine is used to pack products such as poultry hearts, stomachs and livers.

\section{Tab. 2. Identification of stakeholders for packaging line with} OEESIM

\begin{tabular}{|c|c|}
\hline $\begin{array}{l}\text { No of the question } \\
\text { (according to } \\
\text { table 1) }\end{array}$ & Answer \\
\hline 1 & $\begin{array}{l}\text { Packing machine - size, weight, packaging speed, other } \\
\text { parameters are defined in its DTR }\end{array}$ \\
\hline $\begin{array}{cc}- & \text { question 2 } \\
\circ \quad & \text { question 3 } \\
- & \text { question } \\
& 4\end{array}$ & 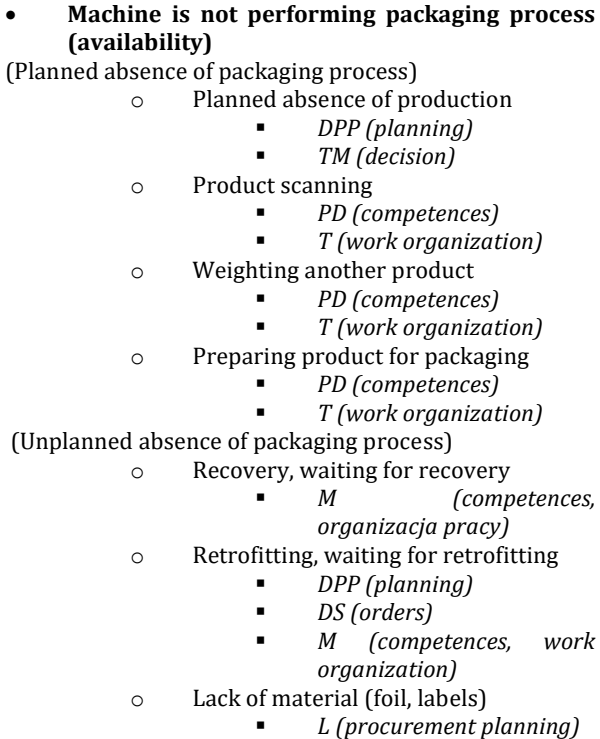 \\
\hline
\end{tabular}




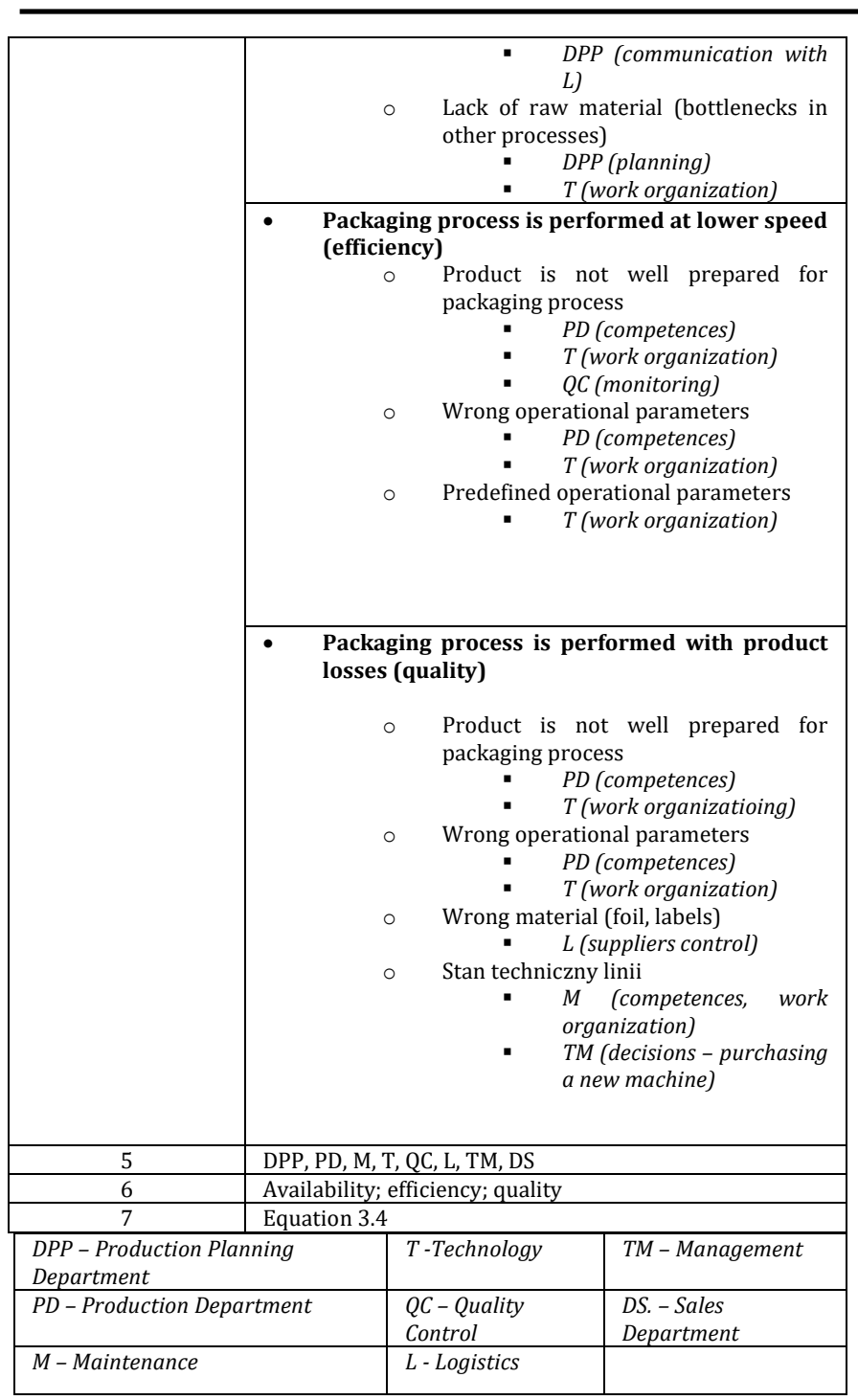

As a result of the methodology implementation, eight stakeholders in the packaging line were identified: Production Planning, Manufacturing, Sales, Maintenance, Logistics, Quality Control, Technology and Management Departments. Similar considerations were made for other lines (slaughtering, cutting and processing), but the number of stakeholders was lower.

The data needed to calculate the availability and performance of OEE components values were obtained through qualitative and qualitative tests - by counting correctly and incorrectly packed products. The study was conducted within 10 working days, during the first and the second shift. Each shift lasted 8 hours, including 0.5 hour breakfast break. This break was not included in the calculation, and the operating time was $t_{\text {all }}=$ $2 \times 8 h-2 \times 0.5 h=15 h=54000 s$. The machine operating times, the times and causes of stops and downtime, and the number of correctly and incorrectly packed products were recorded. The individual components of OEE are shown in the Table 3.

\section{Tab. 3. Calculation of ratios $K_{A}, K_{E}, K_{Q}$ and OEE}

\begin{tabular}{|l|c|c|c|c|}
\hline Ratio & $K_{A}$ & $K_{E}$ & $K_{Q}$ & OEE \\
\hline Average & 0,43 & 0,96 & 0,92 & $\mathbf{0 , 3 8}$ \\
\hline Standard deviation & 0,22 & 0,02 & 0,03 & $\mathbf{0 , 2}$ \\
\hline
\end{tabular}

Changes in the OEE value and its components on individual days are shown in Figure 3.

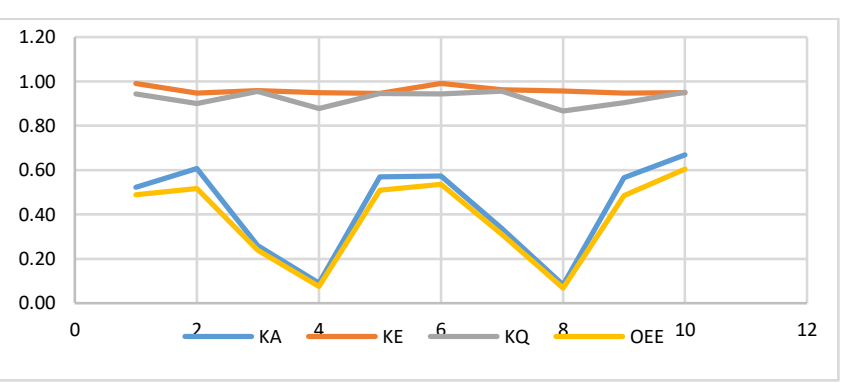

Figure 3. Changes in the OEE value and its components

The analysis of the above graphs shows that the total OEE value depends not only on the efficiency and effectiveness of the Maintenance Department (responsible for the number and time of recovery, the response to ordering of the machine retrofitting and the time of retrofitting), but also on other stakeholders - namely:

- Production Planning Department - as it decides on planned downtime and to some extent is responsible for unscheduled downtime,

- Sales Department - as it determines planned downtime, also affects the number of machines retrofitting,

- Logistics Department - as it decides on the dates and quantity of purchases of material,

- Technology - has a decisive influence on the organization of the packaging process (machine performance) and work organization,

- Production Department - through the competence of personnel it affects the value of the $K_{E}$ and $K_{Q}$.

\subsection{Results}

By analyzing the obtained results it can be concluded that the mean values of the performance indicators $(\mathrm{KE}=0.96)$ and the quality $(\mathrm{KQ}=0.92)$ are relatively large and stable with a small value of standard deviation $(0.02$ and 0.03 , respectively). The average availability index $(\mathrm{KA}=0.43)$ in turn is significantly lower, characterized by high variability (standard deviation is 0.22 ) and has a decisive effect on the OEE average value $=0.38$. The high value of the performance indicator is a consequence of the high qualifications of the operators (the small number of empty packages is the result of properly selected line parameters and proper product preparation). The high value of the quality indicator means high precision of the line and its good technical condition (small numbers of underweight or leakage).

Pareto analysis indicated that the time associated with the planned absence of the packaging process has the greatest impact on the value of OEE. The next are downtimes caused by technological reasons (product preparation, weighing of another product), unplanned downtime (no raw material or materials), and times needed for line retrofitting. The time associated with the recovery is not significant. The time of the absence of the packaging process is the result of the number and size of customer orders and is determined by the Production Planning Department. The times needed to carry out the operations required in the packaging process (raw material preparation, weighing) result from the applied technology and work organization. This time is determined by the Chief Technologist. Unplanned downtime is mainly due to production planning errors (waiting for raw materials, bottlenecks at other stages of the production process) and Purchasing and Logistics (waiting for transparencies, labels, trays). The waiting times for retrofitting and the time of retrofitting the lines are "consumed" by the Maintenance Department, but the frequency of retrofitting is due to the current decision of the Production Planning Department and only the waiting time for recovery and failure recovery t8 is entirely within the responsibility of the Maintenance Department.

This means that analyzing the effectiveness of the use of one packaging machine, selected according to the proposed method, it is possible to obtain information about the functioning of at least five departments of considered company.

\section{Conclusion}

OEESIM (OEE Stakeholders Identification Method) was proposed to ensure, that for OEE measurements and analysis these machines or production lines are selected, for which these measurements give the most added value from the point of view of overall enterprise efficiency (also OEE). Analysis of losses presented in the following paper for packaging 
line proves that only few losses (downtime losses, decreased capacity, quality losses emerging from technical condition etc.) included in OEE are addressed to maintenance department. In addition, other stakeholders with their inputs and influences on line efficiency were identified using OEE SIM: production department (setups, product development, work organization, workstation maintenance), planning department (definition of size and quality of assortment), logistics, procurement as well as Top Management. With proper selection of machine (line, department) and proper defining of losses, OEE can be an indicator that "measures" all aspects concerning the efficient use of equipment and machinery, both qualitative (doing the work correctly) and quantitative (performance of correct work). It can be used to monitor the processes for maintenance of machines but can also be global indicator, the value of which is formed by all or most operating in the enterprise business processes.

\section{References}

[1] M. Tsutsui, S. Takata, Life cycle maintenance planning method in consideration of operation and maintenance integration, Production Planning \& Control: The Management of Operations, 23(2-3), pp. 183193, 2012.

[2] A. Rudawska, N. Čuboňova, K. Pomarańska, D. Stanečková, A. Gola, Technical and Organizational Improvements of Packaging Production Processes, Advances in Science and Technology. Research Journal, Vol. 10, No. 30, pp. 182-192, 2016.

[3] P. Mikołajczak, J. Napiórkowski, Analysing the reliability of working parts operating in abrasive soil pulp taking into consideration confounding factors, Eksploatacja i Niezawodność - Maintenance and Reliability 18 (4), pp. 544-551, 2016.

[4] M. Kaur, K. Singh, I.S. Ahuja: An evaluation of the synergic implementation of TQM and TPM paradigms on business performance. International journal of productivity and performance management, 62 (1), pp. 66-84, 2013.

[5] A. Burduk: Artificial neural networks as tools for controlling production system and ensuring their stability, in: Computer Information Systems and Industrial Management, [in:] Khalid Saeed (eds.) Lecture Notes in Computer Science, Springer, vol. 8104, pp. 487-498, 2013

[6] K.B. Marais, J.H. Saleh, Beyond its cost, the value of maintenance: an analytical framework for capturing its net present value. Reliability Engineering and System Safety 94, pp.644-657,2009.

[7] J. Napiórkowski, P. Szczyglak, K. Kołakowski, Telematics used in the campaigns machinery safety management systems. in: Nowakowski et al. (eds.) Safety and Reliability: Safety and Reliability: Methodology and Applications - Proceedings of the European Safety and Reliability Conference, ESREL 2014 Location: Wroclaw, POLAND Date: SEP 14-18, 2014 Taylor \& Francis Group, London, 2015, pp 1833-1839.
[8] A. Saniuk, M. Jasiulewicz-Kaczmarek, A. Samolejova, S. Saniuk, R. Lenort, Environmental favourable foundries through maintenance activities METALURGIJA 54 (4), pp. 725-728, 2015.

[9] A. Burduk: An attempt to adapt serial reliability structures for the needs of analyses and assessments of the risk in production systems, Eksploatacja i Niezawodność - Maintenance and Reliability, No 3, pp. 8596, 2010

[10] R. Domingo, S. Aguado, Overall Environmental Equipment Effectiveness as a Metric of a Lean and Green Manufacturing System, Sustainability 7, pp. 9031-9047, 2015.

[11] A.S. Relkar, K.N. Nandurkar, Optimizing \& Analising Overall Equipment Effectivenass (OEE) Through Design Of Experiments (DOE). Procedia Engineering 38, pp. 2937-2980, 2012.

[12] M. Jasiulewicz-Kaczmarek, M. Piechowski, Practical aspects of OEE in automotive company - case study, in: Xu, Y; Zhao, S; Xie, H Proceedings of the 2016 International Conference on Management Science and Management Innovation August 13-14, 2016, Guilin, China Book Series: AEBMR-Advances in Economics Business and Management Research Vol. 10 pp. 213-218, 2016

[13] P. H. Tsarouhas, Evaluation of Overall Equipment Effectiveness in the Beverage Industry: A Case Study. International Journal of Production Research 51 (2), pp.515-523, 2013.

[14] P. Kumar, R. Shetty, L.L.R. Rodrigues, Overall Equipment Efficiency and Productivity of a News Paper Printing Machine of a Daily News Paper Company - A Case Study, International Journal of Engineering Practical Research (IJEPR), 3(1), pp. 20-27, 2014.

[15] S. Nakajima, Introduction to TPM. Total Productive Maintenance. Productivity Press, Portland, Oregon. 1988

[16] G. Kłosowski, A. Gola, A. Świć, Application of Fuzzy Logic Controller for Machine Load Balancing in Discrete Manufacturing System, Lecture Notes in Computer Science, Vol. 9375, pp. 256-263.

[17] W.Moczulski, R. Wyczółkowski, K. Ciupke, P. Przystałka, P. Tomasik, D. Wachla,

A methodology of leakage detection and location in water distribution networks - the case study.In: 2016 3rd Conference on Control and FaultTolerant Systems. SysTol'16, Barcelona, Spain, Sept. 7-9, 2016. Conference proceedings. Ed. RamonSarrate. Piscataway : IEEE, 2016, pp. 331-336, 2016

[18] P. Drożyner, Modelling quality of maintenance processes (in polish), Wydawnictwo Uniwersytetu Warmińsko - Mazurskiego, Olsztyn 2017 